\title{
Innate antiviral immunity is impaired in young patients with hand foot and mouth diseases
}

\author{
Y Yang \\ From International Conference on Prevention \& Infection Control (ICPIC 2011) \\ Geneva, Switzerland. 29 June - 2 July 2011
}

\section{Introduction / objectives}

This study was designed to explore the expressions of three pattern-recognition receptors (Toll-like receptor 3, retinoic acid inducible gene-I and melanoma differentiation-associated gene 5) and components of their signaling pathways in the peripheral blood mononuclear cells of children patient with Hand, foot and mouth disease.

\section{Methods}

98 HFMD patients (aged of 1-5 years) and 55 agematched non-infection children were enrolled in this study; the patients were divided into two groups according to clinical characteristics - with or without complications. The expressions of TLR3, RIG-I, MDA5, IRF-1 and IFN-alpha mRNA were detected by Real-Time PCR.

\section{Results}

The expression levels of TLR3 mRNA in HFMD patients were significantly reduced $(6.05 \pm 1.26)$ compared with the non-infection children $(7.05 \pm 0.96), \mathrm{P}<0.001$, and the furthermore decreased was found in the patients with complications $(5.79 \pm 1.15)$. While, the expressions of MDA5 mRNA in all patients including without complications (4.64 \pm 0.49$)$ and with complications (4.60 \pm 0.48 ) were markedly higher than the non-infection children (4.16 \pm 0.35$), \mathrm{P}<0.001$. However, RIG-I mRNA was detected only in $72 / 98$ patients, which was not found in the non-infection children. IFN-alpha was lower in the patients without complications $(5.71 \pm 1.26)$ than the non-infection children $(6.19 \pm 0.86)$, and significantly decreased IFN-alpha mRNA transcriptions were found in the patients with complications $(5.54 \pm 1.18)$, compared with the non-infection children $\mathrm{P}<0.05$. Moreover, the changes of IRF-1 mRNA were similar with IFN-alpha, an evidently reduced level of IRF-1 was in

Children's Hospital of Fudan University, Shanghai, China the patient with complications $(4.89 \pm 0.66)$ compared with the non-infection children (5.32 \pm 0.64$), \mathrm{P}=0.001$.

\section{Conclusion}

It is suggested that innate antiviral immunity is impaired in patients and is possibly correlated with the severity of illness.

\section{Disclosure of interest}

None declared.

Published: 29 June 2011

doi:10.1186/1753-6561-5-S6-P45

Cite this article as: Yang: Innate antiviral immunity is impaired in young patients with hand foot and mouth diseases. BMC Proceedings 20115 (Suppl 6):P45.
Submit your next manuscript to BioMed Central and take full advantage of:

- Convenient online submission

- Thorough peer review

- No space constraints or color figure charges

- Immediate publication on acceptance

- Inclusion in PubMed, CAS, Scopus and Google Scholar

- Research which is freely available for redistribution
() Biomed Central 